GLOBAL JOURNAL OF EDUCATIONAL RESEARCH VOL 17, 2018: 87-95

COPYRIGHT@ BACHUDO SCIENCE CO. LTD PRINTED IN NIGERIA. ISSN 1596-6224

87 www.globaljournalseries.com; Info@globaljournalseries.com

\title{
LIBRARY USE INSTRUCTION AND THE PATTERN OF UTILIZATION OF LIBRARY SERVICES BY UNDERGRADUATES IN THE UNIVERSITY OF CALABAR, NIGERIA
}

\section{JAMES OGOM ODU AND IMELDA BARONG EDAM-AGBOR}

(Received 9, April 2018; Revision Accepted 19, April 2018)

\begin{abstract}
A survey of library use instruction programme and how it influences the pattern of utilization of library resources and services in the University of Calabar was carried out. The population of the study comprised undergraduate library users in the University of Calabar. Accidental sampling technique was used to select 320 respondents who constituted the sample of the study. Questionnaire was the instrument used for data collection. Three hundred and twenty (320) questionnaires were administered to the respondents in the six units of Readers Services Division of the library within a period of 6 days. The data collected was analysed using descriptive statistics (simple percentage \%). The study found out, among others that, the perception of the Library Use Instruction Programme by undergraduates in the University of Calabar was high, resulting to high level of patronage of the library: 84 respondents $(26.3 \%)$ agreed that the programme equips users to make independent use of the library while 80 respondents $(25 \%)$ acknowledge that the skills acquired from the programme aids users academic performance. 70 respondents (21.9) perceive the programme as a means of diversifying users' knowledge while 66 respondents $(20.6 \%)$ noted that the programme is a source of empowerment in information search and retrieval in a library. This was attributed to the possession of basic Library Use skills by undergraduates which were acquired during the Library Use Instruction Programme. It was recommended in the study that the instructional programme should run for both first and second semesters and it should be an independent credit carrying course under the General Studies Programme of the University of Calabar.
\end{abstract}

KEYWORDS: Library use, Instruction, Pattern, Utilization, Library Services, University.

\section{INTRODUCTION}

The nomenclature of the instructional programme on how to use the library varies from one institution to the other. It is variously referred to as: Library Use Instruction, User Education Programme, Bibliographic Instruction, Library Skills or Library Orientation. It consists of "instructional programme designed to teach library users how to locate the information they need quickly, efficiently and independently. It involves teaching library users to acquire basic library use and information literacy skills. It usually covers practical knowledge of the access tools to available information, the library's system of organizing knowledge, electronic resources, reference resources and services, library rules and regulations. It prepares individual library users on how to make immediate and lifelong use of information effectively by teaching the concepts and logic of information access and evaluation, and by fostering information independence and critical thinking. Fleming (1990) defined library use education as various programmes of instruction, education and exploration provided by libraries to users to

James Ogom Odu, (College Librarian), Cross River State College of Education, Akamkpa, PMB 1171, Calabar, Nigeria.

Imelda Barong Edam-Agbor, Department of Library and Information Science, Faculty of Education, University of Calabar, Nigeria.

(C) 2018 Bachudo Science Co. Ltd. This work is licensed under Creative Commons Attribution 4.0 International license. 
enable them to make effective, efficient and independent use of information sources and services to which these libraries provide access.

A library is an information agency saddled with the responsibility of creating access to existing information resources and services for the user community. The information provided is dependent, to a large extent, on the type of library in question. For academic libraries, like the University of Calabar library, the vision of the parent institution is a major determinant of the range of resources and services provided. In academic libraries, emphasise is on research, teaching, learning and community development which formed a major part of the responsibility of their parent institutions. Thus, library resources should be assembled based on the needs of the research community. The various categories of users and their areas of specialization should be considered in addition to making provisions for all the academic programmes and courses offered by the parent institution in the collection development programme of the library. In Library and Information Science profession, provision of relevant information resources in different formats is the focus, while access, utilisation and users' satisfaction with these resources and services is the major goal. To achieve this goal, accessibility, research skills, information literacy and library use competences are basic prerequisites.

These skills are necessary as the first step towards effective utilization of available library resources and services. No matter how large and well stocked a library is, if the resources cannot be accessed and utilized, such a library is meaningless. It is the utilization of library resources and services that infuses life into a library, determine its worth and the perception of its users. Library use leads to users' perception and users' satisfaction or dissatisfaction as the case may be. If library use leads to positive perception of the library and its services, users will find fulfilment for the time spent in the library and a good reason to return to the library again and again. To guarantee accessibility and utilization of library resources and services, both the library and its users have some obligations to fulfil. The library is expected to create a variety of access points to its resources and services by systematically developing their bibliographic surrogates needed to access the resources in the library. The users on the other hand, needed to be equipped with basic information literacy competences and library use skills needed for information search and retrieval. Such competences will place library users in the right perspective to explore available resources and services in the library independently. It becomes imperative to introduce Library Use Instruction Programme designed to teach library users the basic routine processes involved in the search and retrieval of information.

Library resources and services vary and different approaches could be adapted to access and use these invaluable resources and services. The physical library system has its resources and services as well as the access points to these resources. The electronic library also has its resources and services with specific approaches to access and use them. A comprehensive library user instruction programme will instruct users to acquire the competences needed to effectively use both the physical and the electronic library resources and services. Academic libraries work together with other members of their institutional communities to participate in, support, and achieve the educational mission of their institutions by teaching the core competencies of information literacy: the abilities involved in identifying an information need, accessing needed information, evaluating, managing, and applying information, and understanding the legal, social, and ethical aspects of information use. The systematic delivery of instructional programs and services should be planned in concert with overall strategic library planning, including the library's budgeting process.

The content of Library Use Instruction varies among academic institutions. Instruction programmes in academic libraries should have clearly articulated in order to achieve learning outcomes that are aligned with the objectives of the programme. Instruction should employ active learning strategies and techniques that require learners to develop critical thinking skills in concert with information literacy skills. Planning such active learning strategies and techniques should be carried out collaboratively with the various faculties to increase overall students' engagement and to extend opportunities for a more reflective approach to information retrieval, evaluation, and use.

Library use pattern is a reflection of the attitude and the approaches adopted in the search for information in a library. It is a measure of the level of importance attached to the library by its users. There are users who perceived that the library is the ultimate destination in the search for information and therefore they ensure 
compliance to rules and regulations guiding users conduct while in the library. This category of Users would politely approach a staff for assistance where necessary in other to get the desired information. There is another category of users who showed good knowledge of information handling skills. This category of users can independently access and retrieve information from the library. There are users who display delinquencies while using the library: mutilation of library resources, stealing, writing and painting on the pages of books and journals. Each of these library use pattern is a reflection of the users' orientation and information handling skills. That explains the need to ensure efficiency and effectiveness in the training provided during library use instruction programme.

The course content of the instructional programme should be designed to address all routine process needed for information search and retrieval. The instructional process should emphasise obedience to library rules and regulations in addition to acquisition of information literacy and library use competences. The philosophy of the library use instruction should be to prepare library users to acquire basic information literacy and library skills needed for independent search and retrieval of information from both the physical and the electronic library while respecting and obeying the library rules and regulations. Therefore the course content should be designed to address this philosophy in all its ramifications. To be able to achieve this philosophy, and considering the enormity of the course content, the instructional programme should be structured to cover two semesters to guarantee dept and proper training of library users. The teaching method should be diversified to include library visits and practical experience in the university library in addition to the formal training in a classroom setting. Instruction in library use competences and information literacy skills is a valuable and essential part of the school's educational programme. Essential library use competences and information literacy skills encompass more than just location of, and access to resources. The Library Use Instruction Programme's curriculum should emphasize general information related problem-solving skills, research processes and the specific skills to enable users access and apply information to specific needs. Knowledge of bibliographic surrogates and their utilization in information search and retrieval is most paramount. Library and information skills should not be taught in isolation. The programme should be fully integrated with the school's curriculum. The use of innovative instructional methods and technologies can enhance the teaching of library use and information literacy skills.

In the University of Calabar, Library Use Instruction is taught as part of the General Studies Programme of the University. It is subsumed under GSS 1101: Use of English. The English Language component of the course is allocated 80 marks while Library Use Instruction is allocated 20 marks during examination. However, both the English Language teacher and the Library Use Instruction teacher spent the same period of time (3 credit Units) teaching their respective components of the course. A similar discrepancy as above is revealed in the payment of honorarium that accrues from teaching in the General Studies Programme of the University of Calabar. The English Language teacher receives $80 \%$ while the Library Use Instruction teacher gets $20 \%$ of the amount approved for each GSS course taught per semester. This seeming discrimination against Library Use Instruction Programme and those teaching the Course is a potential set back in the moral of Library Use Instruction teachers that is capable of influencing their efficiency, commitment and dedication. In the light of this obvious reality, the effectiveness of the Library Use Instruction Programme in the University of Calabar could become a basic challenge. The obvious consequence of this scenario is a generation of library users without the basic skills and competences on how to use the library.

According to Braimoh et. al (cited in Nwezeh, 2010) the consequences of the students inability to use the library will include among other things, a serious debasement of quality of university education, which may consequently have a negative effect on the job performance of the university products. A great deal of effort is being made to assist fresh undergraduates (the incoming students) into the university in the use of library resources. The attempt which include introduction of user education is to build good library culture into the students' right from the foundation of their university education (Akande, 2003). The need to define the pattern of use of the library and its materials as demonstrated by undergraduates, especially the freshmen, is very significant because it would tell the librarians a lot about the library as the students see or perceive it. Osagie (2003) highlighted reasons why users' education becomes imperative in tertiary institutions. These 
include rapid growth of published materials, changes in methods of teaching and course content, lack of awareness of library services and facilities. Others include users' ignorance, coupled with the fact that students come from diverse background and culture. Palssan, in Etim (2002) confirms that access to and interaction with the library system improves students learning skills and academic performance.

\section{STATEMENT OF THE PROBLEM}

Preliminary observation of library use pattern in the University of Calabar reveals the prevalence of a user category devoid of basic information literacy and library use skills. The users apparently tend to depend on library staff for all their information need. With the Library Use Instruction Programme in place in the University of Calabar, one would expect to see a generation of library users who demonstrates proficiency in the search and retrieval of information. The apparent lack of information literacy skills exhibited by users' call to question the effectiveness of the Library Use Instruction Programme in the University of Calabar. It becomes imperative to conduct this study to ascertain the influence of the Library Use Instruction Programme on the pattern of utilization of library resources and services in the University of Calabar.

\section{OBJECTIVES OF THE STUDY}

This study was designed to ascertain the influence of Library Use Instruction Program in the University of Calabar, Nigeria. Specifically, the study sought to:

1. Ascertain how undergraduate library users' perceive the Library Use Instruction Programme in the University of Calabar.

2. Ascertain the frequency of utilization and the average time spent in the library by undergraduates in the University of Calabar.

3. Assess the library use competences of undergraduates in the University of Calabar.

4. Ascertain the library services most frequently used by undergraduates in the University of Calabar Library.

5. Determine how the Library Use Instruction Programme Influence undergraduates pattern of utilization of library services in the University of Calabar.

\section{REVIEW OF RELATED LITERATURE}

The need to define the pattern of use of the library and its materials as demonstrated by undergraduates especially the freshmen is very significant because it would tell the librarians a lot about the library as the students see it (Nwezeh, 2010). Odusanya (2001) argued that majority of students are not well skilled in the use of catalogues as information retrieval tool. Their findings also showed that manual searching of information through manual library catalogue consume time. According to Rafferty (2013), students cited resources, specifically those highlighted during library instructional sessions, in their assignments. The percentage of all citations coming from resources highlighted during the instructional sessions or found on the course Lib Guide indicates that library instruction had an impact on the students' work.

Bello (2003) stated that library use education is a device by the librarians to educate users on how to use the resources available in the library in a result oriented ways. Since the objectives of the library use education according to Osagie (2003) are: to enable users to know how to use the library catalogues independently in any library with particular references to the Author/Title and Subject Catalogues; to enable users to understand the classification schemes in any library so as to be able to locate materials (books, journals, audio visual materials etc) with little or no problem; to be able to see library catalogues as indexes to the entire collection and use them as such; and to enable the users to see the library as a repository of knowledge that determines the success of the students academic programme. In a study on the effect of library use instruction, Ogunmodede (2010) revealed that $76.1 \%$ of respondents see the instruction as being useful, while the rest do not see the usefulness or are undecided. For lectures on library rules and regulations, about $81.8 \%$ of the students assessed the course to be useful, while the rest do not see its usefulness. The respondents also revealed that the explanations on how to access information in the library is useful, about $71.6 \%$ of the respondents attested to this. The same is applicable to all other sections with the exception of instructions on information technology (computers) in the library, which only $47.4 \%$ respondents revealed that they made use of. In other words, an average students do not see reasons for instructions on information technology probably because they might have been computer literate 
before they were admitted into the University or that they do not understand the concept really.

In a study on the effect of user education programme on undergraduate library exploration at the university of Ilorin, Opaleke (2000) found that much has not been achieved in the realization of the objectives of user education in academic libraries. The analysis in this section so far has shown that though the library use instruction programme is useful to undergraduate students, a closer attention by the management will be required to enhance the effectiveness of the programme. Osinulu (2003) opined that the failure of libraries to teach library users the necessary skills could amount to wasting of library resources as well as efforts and financial resources put into the acquisition, processing and dissemination of information. Ojo-Ade and Jagboro (2000) in a survey of use of subject catalogues in Hezekiah Oluwasanmi Library, Obafemi Awolowo University, Ile-Ife found that users were well informed and versatile in the use of library catalogue especially the Subject Catalogue. The study also revealed that users record high success rate of user searches which was attributed to the respondents knowledge of the use of the library gained from library instruction. Akin-Qjo (1994) states that library instructions would produce intelligent library users. In a study on undergraduate library instruction in Nigeria universities, Nwezeh, (2010) revealed that $600(76.9 \%)$ respondents find the library instruction programme very relevant to their academic work, $170(21.8 \%)$ claimed it was relevant while $10(1.3 \%)$ were unable to decide. Respondents were also asked about the relevance of Library Instruction to their education and $750(96.2 \%)$ claimed it was relevant while 30 (3.8\%) were undecided. Similarly, in the assessment of the present method of teaching library use instruction 741 $(95 \%)$ of respondents were satisfied. Similar studies on library use instruction programme in tertiary institutions in Nigeria included; Busayo, (2003), Oluwadere, (2006) and Ugah, (2007).

\section{RESEARCH METHODOLOGY}

This study was conducted in the University of Calabar library, Calabar, Nigeria. The descriptive survey research method was adopted in this study whose population comprised undergraduate library users in the University of Calabar. Accidental sampling technique was use to select 320 undergraduate library users who constituted the sample of the study. This is because the respondents were met by chance and they were requested to be part of the study. Questionnaire was the instrument used for data collection. Three hundred and twenty (320) questionnaires were administered to the undergraduate library users in the 6 units of Readers Services Division of the library. The questionnaires were administered within a period of 6 days, within which the 320 questionnaire were administered. The data collected was analysed using descriptive statistics (simple percentage \%).

\section{PRESENTATION OF DATA AND DISCUSSION OF FINDINGS}

On the perception of the Library Use Instruction Programme by the respondents, the data collected is presented in table 1.

Table 1: Showing the perception of the Library Use Instruction by the respondents in the University of Calabar.

\begin{tabular}{|l|l|l|l|}
\hline $\mathbf{S} / \mathbf{N}$ & Items & Respondents & $\mathbf{\%}$ \\
\hline 1 & It helps to diversify users' knowledge & 70 & 21.9 \\
\hline 2 & It is a source of empowerment in information search and retrieval & 66 & 20.6 \\
\hline 3 & It equips the users to make independent use of the library. & 84 & 26.2 \\
\hline 4 & The skills acquired aids users academic performance. & 80 & 25 \\
\hline 5 & You cannot comprehend why you are made to take the course & 20 & 6.3 \\
\hline 6 & Total & $\mathbf{2 3 0}$ & $\mathbf{1 0 0}$ \\
\hline
\end{tabular}

The perception of the Library Use Instruction Programme by undergraduates in the University of Calabar is high. 84 respondents $(26.3 \%)$ agreed that the programme equips users to make independent use of the library while 80 respondents $(25 \%)$ acknowledge that the skills acquired from the programme aids users academic performance. 70 respondents 
(21.9) perceive the programme as a means of diversifying users' knowledge while 66 respondents $(20.6 \%)$ noted that the programme is a source of empowerment in information search and retrieval in a library. However, 20 respondents $(6.3 \%)$ do not perceive the programme to be relevant as they could not comprehend or justify why they were made to take the programme. Cumulatively, 300 respondents $(93.7 \%)$ showed a positive perception of the Library Use Instruction Programme of the University of Calabar. The finding on undergraduates' perception of Library Use Instruction in the University of Calabar was positive. This is an indication that the programme is worthwhile and endearing. It is also an indication that the programme requires sustenance and evaluation in order to strengthen and popularise it into a strong attraction even to those yet to see its usefulness. This finding is supported by Oluwadare (2006) in a study of the accessibility and use of the Federal Polytechnic Library, Ado-Ekiti, Nigeria, who revealed that the library was well used. This was affirmed by 100 respondents $(52.6 \%)$ who claimed to have a positive perception of the Library Use Instruction provided, the Library resources available and services provided.

The data collected on the frequency of utilization and the average time spent in the library by undergraduates in the University of Calabar is presented in table 2.

Table 2: Showing the frequency of utilization and the average time spent in the library by undergraduates in the University of Calabar.

\begin{tabular}{|l|l|l|l|l|l|}
\hline $\begin{array}{l}\text { Average time spent in the } \\
\text { library }\end{array}$ & Respondents & $\%$ & Frequency of use of the library & Respondents & $\%$ \\
\hline 30 minutes to one hour & 17 & 5.3 & Once a week & 26 & 8.1 \\
\hline 1 to 2 hour & 31 & 9.7 & Two to three times in a week & 66 & 20.6 \\
\hline 2 to 3 hours & 106 & 33.1 & Three to four times a week & 87 & 27.3 \\
\hline 3 to 4 hours & 92 & 28.8 & Every work day & 123 & 38.4 \\
\hline 4 hours and above & 74 & 23.1 & None-use & 320 & 5.6 \\
\hline Total & 320 & 100 & Total & & 100 \\
\hline
\end{tabular}

The data in table 3 shows that 106 respondents $(33.1 \%)$ spent an average of 2 to three hours in the library daily, 92 respondents (28.8) spent 3 to four hours, 74 respondents (23.1) spent 4 hours and above in the library daily. 31 respondents $(9.7 \%)$ spent 1 to 2 hours while 17 respondents (5.3\%) spent between 30 minutes to one hour in the library daily.

On the frequency of use of the library, the result showed that 123 respondents (38.4) visits the library every work day, 87 respondents $(27.3 \%)$ visits the library three to four times a week, while 66 respondents $(20.6 \%)$ visits the library two to three times a week. Those who visit the library at least once a week were 26 respondents $(8.1 \%)$ while those who do not use the library were 18 respondents $(5.6 \%)$. The above result is indicative of the quality time undergraduates spent each time they visit the library while the frequency of visit is a measure of the value user derived from the library. The high level of patronage of the library stemmed from the acquisition of basic Library Use Kills acquired in the Library Use Instruction Programme.
This finding also agree with that of Onuoha, et al (2013), who studied Undergraduates' Use of Libraries in Federal Universities in South-West, Nigeria and revealed a high level of patronage of the libraries by undergraduates. This was observed in the busy nature of the help desks which, according to them, were heavily utilised as affirmed by 319 $(50.4 \%)$ of the respondents who claim to use the library daily. The finding on the frequency of utilization and the average time spent in the library by undergraduates in the University of Calabar is quite encouraging. Again the finding is in concert with that of Ojo-Ade and Jagboro (2000) who in a survey of use of subject catalogues in Hezekiah Oluwasanmi Library, Obafemi Awolowo University, found that users were well informed and versatile in the use of library catalogue especially the subject catalogue. The study also revealed that users record high success rate of user searches which was attributed to the respondents' knowledge of the use of the library gained from Library Use Instruction. It also agrees with Okiy (2000) who assesses students and faculty use of academic 
libraries in Nigeria with particular reference to Delta State University, Abraka. Although undergraduates constituted the majority of the users, most respondents were found to use the library 2-3 times a week or $2-3$ hours daily. This implies that the library is still relevant in today's academic environment. However, the finding is in disagreement with the findings of Osinulu
(1998) and Akin \& Ajayi (2008) whose studies revealed low level of library use. This implies that the library is still relevant in today's academic environment.

The finding on library use competences of the respondents is also positive. The data on the library use competences of the respondents is presented in table 3 .

Table 3: Showing the library use competences of the respondents.

\begin{tabular}{|l|l|l|l|}
\hline $\mathbf{S} / \mathbf{N}$ & Items & Respondents & $\mathbf{\%}$ \\
\hline $\mathbf{1}$ & Knowledge of the physical catalogue and how to use it & 67 & 20.9 \\
\hline $\mathbf{2}$ & Knowledge of OPAC and how to use it & 12 & 3.8 \\
\hline $\mathbf{3}$ & Knowledge of bibliographic surrogates as access points & 24 & 7.5 \\
\hline $\mathbf{4}$ & Knowledge of circulation services and how to borrow books & 105 & 32.8 \\
\hline $\mathbf{5}$ & Knowledge of library rules and regulations & 67 & 20.9 \\
\hline $\mathbf{6}$ & Obedience and respect for library rules and regulations & 45 & 14.1 \\
\hline & Total & $\mathbf{3 2 0}$ & $\mathbf{1 0 0}$ \\
\hline
\end{tabular}

Table 3 shows the library use competences of undergraduates in the University of Calabar. 105 respondents $(32.8 \%)$ have good knowledge of circulation services and the procedure to follow in order to borrow books from the library. 67 respondents $(20.9 \%)$ have good knowledge of the physical catalogue while another 67 respondents $(20.9 \%)$ showed good knowledge of library rules and regulations. Those who showed respect and obedience to library rules and regulations were 45 respondents $(14.1 \%)$ while those who have knowledge of OPAC and how to use it were 12 respondents $(3.8 \%)$. This finding is in concert with that of Ojo-Ade and Jagboro (2000), who surveyed the use of the library catalogues in Hezekiah Oluwasanmi Library, Obafemi
Awolowo University, lle-Ife, Nigeria. The study found that users were well informed and versatile in the use of library catalogue especially the subject catalogue. The study also revealed that users recorded high success rate of user searches which was attributed to the respondents knowledge of the use of the library gained from Library Use Instruction. However, the result is at variance with that of Odusanya (2001) who found that majority of students are not well skilled in the use of catalogues as information retrieval tool. Their findings also showed that manual searching of information through manual library catalogue consume time.

The data on the library services most frequently utilized by undergraduates in the University of calabar is presented in table 4.

Table 4s: Showing the most frequently used library services by undergraduates in the University of Calabar.

\begin{tabular}{|l|l|l|l|}
\hline $\mathbf{S} / \mathbf{N}$ & Items & Respondents & \% \\
\hline 1 & Lending services & 84 & 26.3 \\
\hline 2 & Photocopying services & 102 & 31.9 \\
\hline 3 & Reference services & 54 & 16.9 \\
\hline 4 & Internet access & 38 & 11.8 \\
\hline 5 & Access to electronic resources & 17 & 5.3 \\
\hline 6 & Reading of newspaper collections (current awareness) & 21 & 6.6 \\
\hline 7 & None-use of library services & 4 & 1.2 \\
\hline $\mathbf{8}$ & Total & $\mathbf{3 2 0}$ & $\mathbf{1 0 0}$ \\
\hline
\end{tabular}


The result on the most frequently utilised library services by undergraduates in the University of Calabar revealed that 102 respondents $(31.9 \%)$ use photocopying service more, followed by lending services (26.3\%), reference services (16. 9\%), internet access $(11.8 \%$, current awareness services $(6.6 \%)$, access to electronic resources $(5.5 \%)$ and lastly those who do not use the library were 4 respondents (1.2\%). The undergraduates' demonstrated good knowledge of basic library routine services as indicated in their utilization of the various library services as shown in table 4. This is in agreement with the finding of Nwezeh (2010), who in a study of Undergraduate Library Instruction in Nigerian Universities: A Case Study of Hezekiah Oluwasanmi Library, Obafemi Awolowo University, lle-Ife, Nigeria found that all types of publications are used though in varying degrees: $420(54 \%)$ of the respondents sourced information from books, $120(15 \%)$ of the respondents used journals, $45(6 \%)$ of the respondents used indexes and abstracts, 35(4\%) of the respondents used non-print media, 90 $(12 \%)$ of the respondents used reference materials, $50(6 \%)$ of the respondents used government publications while $17(2 \%)$ of the respondents obtained information from newspapers and magazines.

The data on how the Library Use Instruction Programme influence the pattern of utilization of Library services by undergraduates in the University of Calabar is presented as follows: As a result of the Library Use Instruction Programme, 102 respondents (31.9\%) perceived the library as the solution to their information needs while it also creates a positive image of the library on 85 respondents (26.5\%). 79 respondents $(24.7 \%)$ acknowledged that the programme draws attention to avoidable acts of delinquencies most often exhibited by library users while 54 respondents $(16.9 \%)$ revealed that the programme is a guide on the arrange of resources in their respective disciplines and where such resources are actually located in the library.

This is an indication that the Library Use Instruction Programme in the University of Calabar exerts a positive influence on undergraduates pattern of utilization of library services in the University of Calabar. When users perceive the library as the ultimate solution to their information needs, they will invariably hold the library in high esteem and make conscious efforts to benefit from available library services. The positive image of the library created in the mind set of undergraduates is like a binding force that would continue to draw the undergraduate users to the library over and over again.

\section{CONCLUSION AND RECOMMENDATIONS}

Provision of Library resources and services in the desired format, quality and magnitude is a measure of the readiness of academic libraries to meet the information needs of their users. However, effective utilization of these resources and services is a function of the library use competences exhibited by library users. This therefore, is the imperative of Library Use Instruction Programme provided in tertiary institutions in Nigeria. The library users are to be equipped with the basic skills needed to explore the resources and services in the library. The essence is to guarantee proper use of the library thereby reducing the prevalence of juvenile delinquencies to the barest minimum, ensure safety of available resources and continuity in the provision of library services. This is important because, no matter how rich a library is, in terms of the quality of its resources and services, what determines its worth is the extent of utilization of its resources and services. In other words, a library whose resources and services are not being utilised is dead.

Therefore, to keep the academic libraries alive to their responsibilities requires a holistic Library Use Instruction Programme that should be an independent course in the General Studies programme of the University. Besides, it should be taught in both first and second to properly prepare the users for effective use of the library.

\section{REFERENCES}

Akande, S. 0., 2003. Patterns of first-year students use of a university library: A Survey of University of Ibadan. Lagos Journal of Library and Information Science, 2(1); 22-26.

Akin, A. O and Ajayi, P. O., 2008. Students' utilization of academic libraries in Nigeria: A case study of Federal University of Technology, Akure between year 2001-2005. Asian Journal of Information Technology 7(5):172-174. 
Akin-Ojo, J., 1994. Conscience of exhibition, library orientation and effective use of the Library: A case study of the University of Lagos. Lagos Librarian, 15: 11-17.

Akinade, J. O., 2000. Nigerian medical libraries: Challenges for the 21s'1 century. Nigerian Libraries, 34 (1):46-54.

Bello, A. S., 2003. Library User Education Evaluation at the Ibadan Polytechnic. Nigerian Library and Information Science Review 21(1):1-6.

Busayo, I. O., 2003. Use of the Library as a requisite course: $A$ survey of the perception of University of Ado Ekiti freshmen. Gateway Library Journal $6(1): 44-52$

Fleming, H., (Ed.) 1990. User education in academic libraries. London: Library Association Publishing Limited.

Nwezeh, C. T. M., 2010. Undergraduate library instruction in Nigerian universities; A case study of Hezekiah Oluwasani library, Obafemi Awolowo University Library, Ile-lfe, Nigeria. Library Philosophy and Practice.

Odusanya, O. K., 2001. Catalogue use in a Nigerian University system: A case study of Olabisi Onabanjo University, AgoIwoye. Gateway Library Journal, 3 (1 \& 2): 59-65.

Ogumodede, T. A and Emeahara, E. N., 2010. The effect of library user education as a course on library patronage; A case study of LAUTECH, Ogbomosho, Nigeria. Library Philosophy and Practice. Online

Ojo-Ade, C. O and Jagboro, K. O., 2000. Subject catalogue use at Hezekiah Oluwasanmi Library, Obafemi Awolowo University, Ile-Ife, Nigeria. African Journal of Library. Archives and Information Science, 10(2): p. 177.

Okiy, R. B., 2000. Assessing students and faculty use of academic libraries in Nigeria: The study of Delta State University Abraka. Frontiers of
Information and Library Science 1(1): 65-75

Oluwadare, I. B., 2006. Accessibility and use of library resources by part-time students: A case study of the Federal Polytechnic, Ado-Ekiti, Nigeria. Library Review, 55(2), 148-156.

Onuoha, U. D., Ikonne, C. N and Madukoma, E., 2013. Perceived impact of library use on the Research productivity of postgraduate students at Babcock University, Nigeria. IOSR Journal of Research \& Method in Education 1(1):11-16

Onuoha, U. D and Subair, M. O., 2013. Undergraduates use of libraries in federal universities in south west Nigeria. Library Philosophy and Practice. Online

Opaleke, J. S., 2002. Effect of the user education programme on undergraduate library exploration at the University of Ilorin. The International Information and Library Review 30 (4): 275 - 287

Osagie, J. N., 2003. User education in tertiary institution in Nigeria. Lagos Journal of Library and Information Science, 1 (1):32-36.

Osinulu, L. F., 2003. Undergraduate library instruction at the Olabisi Onabanjo University. Lagos Journal of Library and Information Science, 2(1):11-15.

Palssan, J. in Etim, Felicia, E. E., 2002. Integrating information handling skills into the Curriculum: A panacea of education reforms in secondary schools in Nigeria, Nigerian Libraries, 36(1):2329.

Ugah, A. D., 2007. Evaluating the use of university libraries in Nigeria: A case study of Michael Okpara University of Agriculture, Umudike. Library philosophy and practice. Online. 
